Portland State University

PDXScholar

$12-1-2019$

\title{
Assessing the Barriers to Equity in Smart Mobility Systems: A Case Study of Portland, Oregon
}

\author{
Aaron Golub \\ Portland State University, agolub@pdx.edu \\ Vivian Satterfield \\ Verde \\ Michael Serritella \\ Portland Bureau of Transportation \\ Jai Singh \\ Asian Pacific American Network of Oregon \\ Senna Phillips \\ Cornell University
}

Follow this and additional works at: https://pdxscholar.library.pdx.edu/usp_fac

Part of the Urban Studies and Planning Commons

Let us know how access to this document benefits you.

\section{Citation Details}

Golub, A., Satterfield, V., Serritella, M., Singh, J., \& Phillips, S. (2019). Assessing the barriers to equity in smart mobility systems: A case study of Portland, Oregon. Case Studies on Transport Policy.

This Post-Print is brought to you for free and open access. It has been accepted for inclusion in Urban Studies and Planning Faculty Publications and Presentations by an authorized administrator of PDXScholar. Please contact us if we can make this document more accessible: pdxscholar@pdx.edu. 


\title{
ASSESSING THE BARRIERS TO EQUITY IN SMART MOBILITY SYSTEMS: A CASE STUDY OF PORTLAND, OREGON
}

\author{
Aaron Golub \\ Associate Professor and Director \\ Nohad A. Toulan School of Urban Studies and Planning \\ Portland State University \\ 560 SW Mill St. \\ Portland, OR 97201 \\ agolub@pdx.edu \\ $+1-503-725-4069$ \\ Vivian Satterfield \\ Verde \\ viviansatterfield@gmail.com \\ Michael Serritella \\ Portland Bureau of Transportation \\ serritella.mike@gmail.com \\ Jai Singh \\ Asian Pacific American Network of Oregon \\ jairajsingh@gmail.com \\ Senna Phillips \\ Cornell University \\ snp34@cornell.edu
}

Acknowledgements: This project was funded by grants from Forth (https://forthmobility.org/), the $11^{\text {th }}$ Hour Project (of the Schmidt Family Foundation), and the National Institute for Transportation and Communities (NITC) at Portland State University (Project \#1163), a U.S. DOT University Transportation Center, with assistance from the City of Portland.

HOW TO CITE:

Golub, A., Satterfield, V., Serritella, M., Singh, J., \& Phillips, S. (2019). Assessing the barriers to equity in smart mobility systems: A case study of Portland, Oregon. Case Studies on Transport Policy, 7(4), 689-697. https://doi.org/10.1016/j.cstp.2019.10.002 
2 ASSESSING THE BARRIERS TO EQUITY IN SMART MOBILITY SYSTEMS: A 3 CASE STUDY OF PORTLAND, OREGON

\section{ABSTRACT}

5 There is an active debate about the potential costs and benefits of emerging "smart mobility" 6 systems, especially in how they will serve communities already facing transportation challenges.

7 This paper describes the results of an assessment of these equity issues in the context of lower8 income areas of Portland, Oregon, based on a mixture of quantitative and qualitative research.

9 The study found that by lowering costs and improving service for public transit, ridesharing and 10 active transportation, smart mobility systems could address many of the needs of transportation 11 disadvantaged communities. Similar to those found in other case studies, significant barriers

12 prevent smart mobility technologies from benefiting all communities. For example, lower

13 income survey respondents and respondents of color had significantly lower access to the "smart 14 mobility ecosystem" including bank accounts and credit cards, they rely more heavily on paying 15 cash for transit tickets, had lower access to internet at home and work, and were more likely to 16 reduce data use or cancel cell plans because of cost or data restrictions. Respondents were also 17 concerned about information security, as the impacts of loss or theft, especially identity theft can 18 be devastating for lower-income residents. Since integrating payment systems and relying on 19 internet and cell data for mobile applications is a core feature of smart mobility ecosystem, these 20 disparities are significant barriers to the equitable transition to smart mobility. Policy

21 recommendations to address barriers include expanding free and public WiFi, better real-time 22 transit information, improved training, and language translation for phone applications, among 23 other things. 
2 There is an active and ongoing debate about the potential costs and benefits of emerging 3 Information and Communication Technologies (ICT), autonomous, electric, connected and 4 shared mobility technologies and services - broadly classified here as "smart mobility" systems. 5 This project focuses on the user end of these systems - how users will access information and reserve and pay for services provided through a smart mobility "ecosystem" of technologies, accounts and devices. One particular dimension of the debate is how these new technologies will affect communities already facing transportation disadvantage, who are often marginalized within transportation planning or decision-making processes, who often don't benefit from investments in transportation (e.g. because of affordability or lack of access to a private vehicle), and who often bear the burdens from investments (e.g. infrastructure impacts on neighborhoods). This project explores these overlapping issues - present-day transportation disadvantage and the potential for new investments and technologies to either alleviate or exacerbate existing

Innovation in smart mobility systems has been primarily driven by a consortium of private interests including automobile manufacturers (Ford, GM, Volvo, etc.), transportation network companies (TNCs) (e.g. Uber, Lyft, etc.), and major technology companies (Google, Apple, etc.). The City of Portland, TriMet (Portland's regional public transit provider) and other local leaders, neighborhoods, and community organizations are working to design and implement a smart mobility plan to insure issues important to the public are protected as smart mobility systems are deployed. This plan was heavily shaped by The Portland Smart Cities UB Mobile PDX proposal (PBOT 2018), developed in response to a request for proposals from the United States Department of Transportation (the application was a national finalist, yet was not chosen). The proposal focused strongly on developing mobility solutions that would serve traditionally underserved populations (low-income, communities of color, older adults, and residents with mobility challenges). This paper won't break out results for residents with mobility challenges as those issues are being analyzed in a subsequent project.

The research described in this paper is part of this planning effort by developing an equity assessment of smart mobility systems in the Portland context. This project was carried out through a collaboration between the City of Portland, Forth, OPAL Environmental Justice, a non-profit organization focused on housing, transportation and environmental justice, and Portland State University (Golub et al. 2018). Specifically, this project explores the following research questions:

1. How can smart mobility technologies address the current and future needs of transportation disadvantaged communities (defined here as racial/ethnic minorities, low-income, and older adults)?

2. What are the barriers to using smart mobility technologies experienced by transportation disadvantaged communities?

3. What potential solutions show the most promise in overcoming these barriers?

In the first sections of this paper, the relevant existing literature is reviewed and related to our research questions. Then, the project's research approach and methodologies are presented, along with some background on the Portland case study area. The next section reviews the focus

46 groups and their results. The next section explores the larger sample survey, detailing the survey 
1 methods and study area followed by results. The report concludes with a discussion of these

2 results and their implications.

\section{LITERATURE REVIEW}

The broad introduction of ICT, autonomous vehicle (AV) technologies, and more generally "transportation as a service" using shared and or connected vehicles will significantly alter transportation systems and traveler behavior. To conveniently utilize these smart mobility systems, however, the user must access various support systems and resources which form a smart mobility ecosystem, including internet and cell data, banking and credit accounts, all linked into an on-line and smartphone environment. Therefore, even as virtual mobility (via ICT) grows as a potential replacement for physical mobility, disparities in access to ICT resources and skills could translate into disparities in mobility in the physical world. Setting the stage for this study, there is a growing and important literature on these disparities which both explores currently available smart mobility applications ("apps" offering shared cars or bicycles, rides sourced through TNCs, or other real-time information such as routing or transit vehicle arrivals and payment) as well as future smart mobility systems based on autonomous vehicles (AVs).

To begin, racial and ethnic minorities and low income households are more likely to face transportation challenges due to a combination of lower incomes, lower rates of private car ownership, a greater dependence on public transit and in many regions, jobs and housing spatial mismatch (Kramer and Goldstein 2015, Lubitow et al. 2016, Mattioli and Colleoni 2016). Therefore, providing reliable, diverse and affordable transportation options is critical for ensuring basic levels of social inclusion of all groups. The potential for currently available smart mobility systems (e.g. TNCs, bike sharing or car sharing) to expand access to automobiles for car-less households has been noted by previous studies (McNeil et al. 2017, Howland et al. 2017, Dill et al. 2017, Schaller 2016, Brown 2017, 2019). Other literature postulates that future smart mobility systems (e.g. Mobility As A Service (MAAS) subscription services would further reduce the need for car ownership and licensure, two significant barriers to transportation equity (Acheampong et al. 2018, Iacobucci et al. 2017, Gruel et al. 2016, Grush and Niles 2017, Hörl et al. 2016, Litman 2017). Additionally, real-time information may improve the public transportation experience overall (Alessandrini et al. 2015, Rode et al. 2017, Velaga et al. 2012) and could allow for more demand-based scheduling and improved paratransit.

Alongside potential benefits, the literature uncovers significant barriers to broader access to smart mobility systems. Barriers to the smart mobility ecosystem, due to "digital divide" or "banking divide" create significant barriers to broader access (Dinning and Weisenberger 2017, Schaller 2016, Kodransky and Lewenstein 2014, Brakewood and Kocur 2013, Brown 2017 and 2019). The Federal Deposit Insurance Corporation (FDIC) regular measures banking access, and its most recent 2017 study showed that $6.5 \%$ of the US population was completely unconnected to the mainstream banking system, with another $18.7 \%$ relying on some financial services outside of the insured banking system (FDIC 2018). The smart mobility ecosystem, relying on seamless integration with mainstream banking and credit system, may leave these individuals behind. Mattioli and Colleoni (2016) address the rise in virtual mobility payments and King and Saldarriaga (2017) document significant potential inequities from taxis moving to credit-card

44 based payment systems in New York City. Similarly, Brakewood and Kocur (2013) address 
1 issues facing unbanked riders in Chicago and identify potential solutions. McNeil et al. (2017)

2 explore barriers to bike share access, and illustrate the difficulties for low income and people of

3 color when bike share programs fail to accept diverse payment methods and rely on private data

4 access. Kodransky and Lewenstein (2014) highlight how many low-income riders may not trust

5 institutions with their private and financial information. Detailed case studies in Los Angeles

6 (Brown 2017, 2019) and Boston (Gehrke et al. 2018) explore equity issue in existing TNC

7 service coverage and use, finding that coverage of services are broad and equitable, while actual

8 use is higher among ethnic and racial minorities. (Other work by Feigon and Murphy (2018),

9 however, seems to question the extent of this higher use).

11 Age is also a dimension of potential transportation disadvantage due to technological illiteracy,

12 lack of trust, and other access barriers (Shaheen et al. 2017). A qualitative study by Shirgaokar

13 (2018) uncovered several key barriers to the use of TNCs by older adults in Canada, including a

14 basic lack of knowledge about smartphone and internet, concerns about financial privacy and

15 security issues with smartphone and internet applications, alongside physical safety using TNCs.

17 Synthesizing from this literature, barriers exist along the social dimensions of race, ethnicity,

18 language, class and age (and Shaheen et al. (2017) also emphasizes dimensions of space and

19 time-of-day availability as creating additional barriers). In Table 1, we summarized some of the

20 major equity issues existing along these different social dimensions for some of the key

21 components of the smart mobility ecology, including banking, credit, smartphone ownership, cell

22 service affordability, internet access at home and access to and use of existing new mobility

23 services. In most cases the disparities are clear, while in some, such as in smartphone ownership,

24 internet access and use of existing smart mobility options, the literature is mixed. We can return

25 to these issues when we analyze our results from this case studies. 
1 Table 1. Key disparities in access to the smart mobility ecosystem

\begin{tabular}{|c|c|c|c|c|}
\hline & Age & Income & Race/Ethnicity & Overall averages \\
\hline 电 & $\begin{array}{l}\text { Older population } \\
\text { higher access (FDIC } \\
\text { 2018B Table A1, also } \\
\text { Brakewood and } \\
\text { Kocur 2013) }\end{array}$ & $\begin{array}{l}\text { Higher income population } \\
\text { higher access (FDIC } \\
\text { 2018B Table A.1, also } \\
\text { Brakewood and Kocur } \\
\text { 2013) }\end{array}$ & $\begin{array}{l}\text { White households higher } \\
\text { access (FDIC 2018B Table } \\
\text { A.1, also Brakewood and } \\
\text { Kocur 2013) }\end{array}$ & $\begin{array}{l}87 \% \text { use some } \\
\text { banking resources, } \\
67 \% \text { "fully banked" } \\
\text { (FDIC } 2018 \text { p. } 2 \text { ) }\end{array}$ \\
\hline 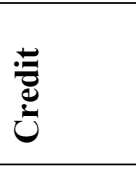 & $\begin{array}{l}\text { Very young and very } \\
\text { old have lower access } \\
\text { to credit (FDIC } \\
2018 \text { B Table F.1) }\end{array}$ & $\begin{array}{l}\text { Higher income population } \\
\text { higher access (FDIC } \\
\text { 2018B Table F.1) }\end{array}$ & $\begin{array}{l}\text { White and Asian households } \\
\text { higher access (FDIC 2018B } \\
\text { Table F.1) }\end{array}$ & $\begin{array}{l}80.3 \% \text { access to } \\
\text { some credit (FDIC } \\
2018 \text { p. } 10)\end{array}$ \\
\hline 这 & $\begin{array}{l}\text { Younger, higher } \\
\text { ownership (FDIC } \\
2018 \text { B, Table B.16, p } \\
65 \text { and Pew 2015, p. } \\
\text { 13) (Also Shirgaokar } \\
\text { 2018) }\end{array}$ & $\begin{array}{l}\text { Higher income population } \\
\text { higher ownership (FDIC } \\
\text { 2018B Table B.16, and } \\
\text { Pew } 2015 \text { p. 13) }\end{array}$ & $\begin{array}{l}\text { Mixed results: FDIC } \\
\text { (2018B): Black lower, and } \\
\text { Asian higher than average } \\
\text { ownership (Table B.16); Pew } \\
\text { (2015): Black and Hispanic } \\
\text { higher rate of ownership (p. } \\
\text { 13). }\end{array}$ & $\begin{array}{l}\text { 2017: 72.7\% (FDIC } \\
\text { 2018B Table B.16) }\end{array}$ \\
\hline 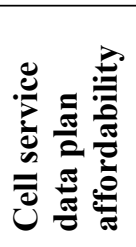 & $\begin{array}{l}\text { Younger more likely } \\
\text { than average to let } \\
\text { service lapse (Pew } \\
2015 \text { p. 14) }\end{array}$ & $\begin{array}{l}\text { Low-income households } \\
\text { about twice as likely as } \\
\text { average to let service } \\
\text { lapse (Pew } 2015 \text { p. 14) }\end{array}$ & $\begin{array}{l}\text { African Americans and } \\
\text { Latinos are around twice as } \\
\text { likely as } \\
\text { whites to let service lapse } \\
\text { (Pew 2015, p. 14) }\end{array}$ & $\begin{array}{l}23 \% \text { of smartphone } \\
\text { owners let cell } \\
\text { service lap (Pew } \\
2015 \text { p. 14) }\end{array}$ \\
\hline 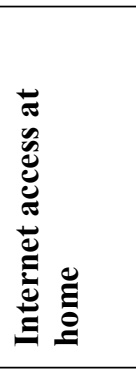 & $\begin{array}{l}\text { Mixed results: High } \\
(0 \mathrm{ver} 75 \%) \text { across the } \\
\text { age groups until } \\
\text { tapering off over } 55 \\
\text { (FDIC } 2018 \mathrm{~B} \text { Table } \\
\text { B.17). Pew (2015) } \\
\text { reports higher access } \\
\text { (more than } 94 \%) \text { for } \\
\text { those over } 50 \text { (p. } 18) \text {. }\end{array}$ & $\begin{array}{l}\text { Higher income population } \\
\text { higher access (FDIC } \\
(2018 B) \text { Table B.17 and } \\
\text { Pew (2015) p. 18) }\end{array}$ & $\begin{array}{l}\text { Black lower, and Asian } \\
\text { higher, than average (FDIC } \\
\text { 2018B Table B.16). Pew } \\
\text { (2015) shows lower access } \\
\text { among African American and } \\
\text { Hispanics compared to } \\
\text { whites (p. 18). }\end{array}$ & $\begin{array}{l}72.6 \% \text { of } \\
\text { households have } \\
\text { internet access at } \\
\text { home (FDIC 2018B } \\
\text { Table B. 17). Pew } \\
\text { (2015) reports } 90 \% \\
\text { have access to } \\
\text { broadband. }\end{array}$ \\
\hline 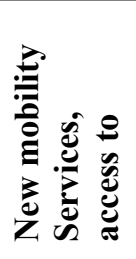 & $\begin{array}{l}\text { No spatial } \\
\text { deficiencies in access } \\
\text { to TNC services in } \\
\text { L.A. case (Brown } \\
2019 \text { p. } 87 \text { ) }\end{array}$ & $\begin{array}{l}\text { No spatial deficiencies in } \\
\text { access to TNC services in } \\
\text { L.A. (Brown } 2019 \text { p. } 87 \text { ). } \\
\text { Bikeshare and carshare } \\
\text { availability appears to be } \\
\text { equitable (Schaller 2016) }\end{array}$ & $\begin{array}{l}\text { No spatial deficiencies in } \\
\text { access to TNC services in } \\
\text { L.A. case (Brown } 2019 \text { p. } \\
\text { 87). Bikeshare and carshare } \\
\text { availability appears to be } \\
\text { equitable (Schaller 2016) }\end{array}$ & $\begin{array}{l}\text { Geography of } \\
\text { services varies by } \\
\text { region }\end{array}$ \\
\hline 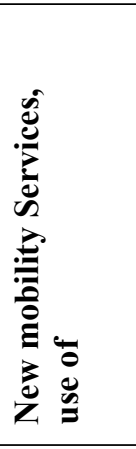 & $\begin{array}{l}\text { Barriers to use due to } \\
\text { technology } \\
\text { proficiency } \\
\text { (Shirgaokar 2018); } \\
\text { Higher TNC use } \\
\text { among younger } \\
\text { population (Schaller } \\
2016 \text { p. 24) }\end{array}$ & $\begin{array}{l}\text { Mixed results: Schaller } \\
(2016) \text { reports higher use } \\
\text { of TNCs among higher } \\
\text { income (p. 26). Rayle et } \\
\text { al. (2016) report moderate } \\
\text { income (and collage } \\
\text { educated) highest users of } \\
\text { TNCs. Gehrke et al } \\
\text { (2018) report incomes of } \\
\text { users similar to the rest of } \\
\text { the Boston region. }\end{array}$ & $\begin{array}{l}\text { Mixed results: Higher } \\
\text { frequency (per capita trips) of } \\
\text { TNC use among ethnic and } \\
\text { racial minorities (Shaheen } \\
\text { 2017, Brown 2019, and } \\
\text { Schaller 2016). Feigon and } \\
\text { Murphy (2018) report is } \\
\text { inconclusive - whiter } \\
\text { neighborhoods generate more } \\
\text { trips, but not in all regions } \\
\text { studied (p. 23) }\end{array}$ & $\begin{array}{l}\text { A few percent of all } \\
\text { trips (varies by } \\
\text { region - no national } \\
\text { data }\end{array}$ \\
\hline
\end{tabular}

3 Finally, the literature points to a variety of potential solutions to closing many of these important 4 disparities in access. The literature suggests expanding payment options to create alteratives to 5 the need for credit or banking (McNeil et al. 2017), investing in public internet or wi-fi networks 
(Shaheen et al. 2017), building more robust outreach and educational programs (Shirgaokar 2018 and McNeil et al. 2017), and addressing important data privacy issues throughout the smart mobility ecosystem (Kodransky and Lewenstein 2014).

This project will supplement the existing literature by adding another city-specific case study to the national debate and as a comparison to the other city-specific cases. Notably, this study's focus on a particular area of a medium-sized metro will differ from the previous case studies

8 based in major metros (Boston, Los Angeles, San Francisco) and also that it is focused on a low-

9 income area of the region.

\section{PORTLAND CASE STUDY}

11 The focus of this study is the smart mobility planning process being developed based on The

12 Portland Smart Cities UB Mobile PDX proposal (PBOT 2018). Portland is the largest metro area

13 in the state of Oregon, with a population of around 2 million, and is located in the northwest

14 region of the United States. This study was designed to illuminate the transportation challenges

15 of lower-income residents and residents of color in the Portland region, so the study area focused

16 on East Portland and west Gresham neighborhoods which are known to have higher

17 concentrations of residents of color and households below the poverty line. East Portland is one

18 of several outer areas of the region that have been "receiving" lower-income residents displaced

19 from rapidly gentrifying neighborhoods in the desirable core of the region, while it is also the

20 site of first settlement for international refugees (such as Somalia) and lower-income immigrants,

21 especially Asian and Hispanic. These areas of the region are becoming increasingly recognized

22 for this important role, and transportation policy and investment attention is being directed

23 towards this area (for example, bus services were recently added to this area). Significant

24 existing research has been carried out recently in East Portland-area communities about

25 transportation challenges and disadvantages (e.g., Lubitow et al., 2016). That research illustrated

26 some clear dimensions of transportation disadvantage experienced by these communities,

27 including lower rates of car ownership and access, existing transit services deficiencies (network

28 coverage, service time of day, travel times, headways and wait times, and costs); lack of

29 sidewalk coverage and resulting safety concerns; and general transportation costs and distances

30 to opportunities create barriers to mobility. Figure 1 shows the study area outlined in red. 


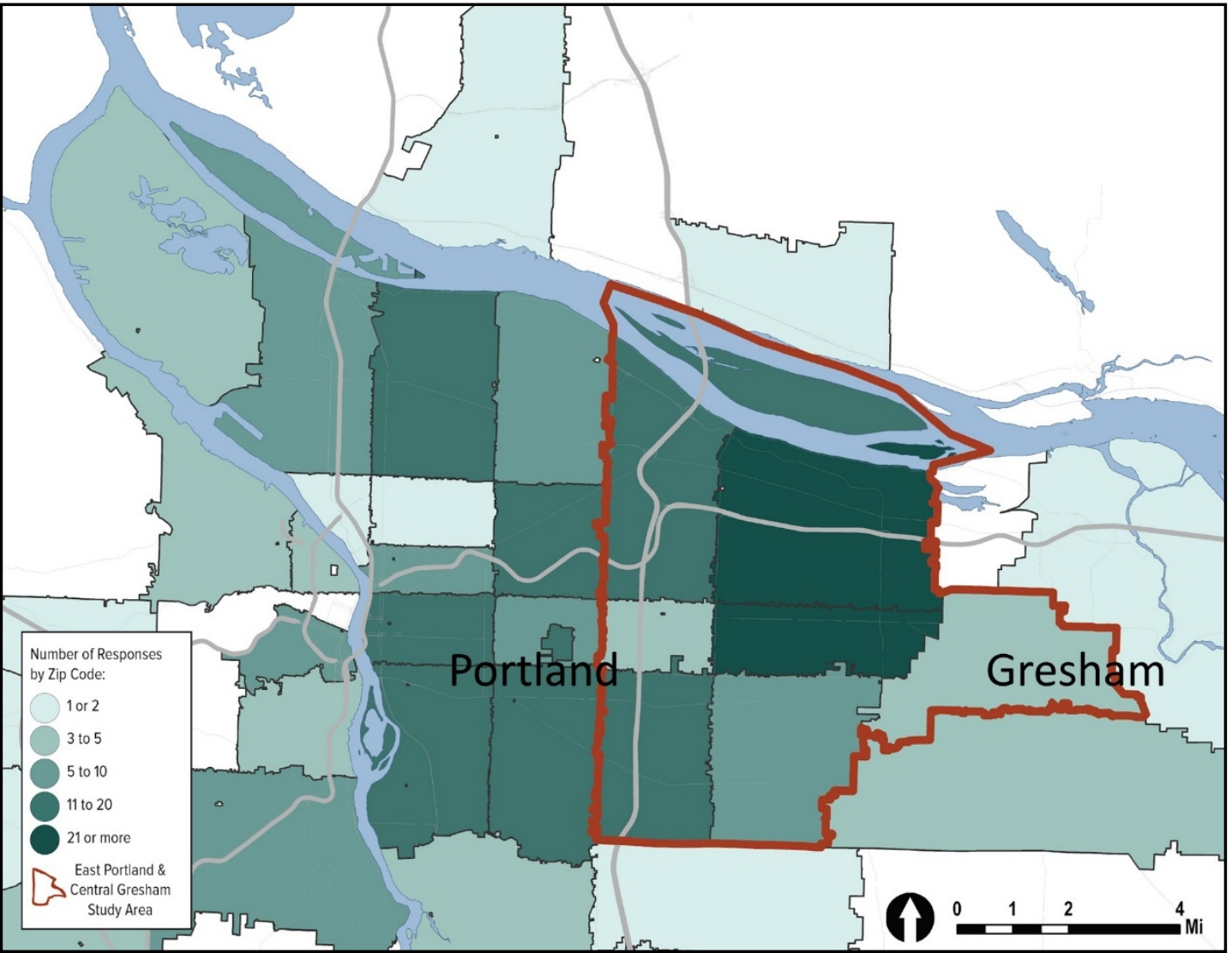

Source: Spatial Data - RLIS (accessed via PSU server)

\section{RESEARCH METHODS}

7 To answer the research questions listed above, it was decided that a mixture of both quantitative

8 and qualitative research would be appropriate. Qualitative methods typically employed with

9 research of this nature include interviews and focus groups. Quantitative methods include larger

10 sample surveys which can reveal numerical and statistical patterns in data. Combined, these

11 methods can create an interwoven and layered understanding of the issues where deeper stories

12 from individuals and small groups can be juxtaposed by data from a larger sample survey.

13 Further, the qualitative information was used to inform the design of the larger sample survey

14 instrument. By spending time in conversation with communities the research team could better

15 understand the specific issues, terminologies and dimensions of the equity challenges. This

16 project began with focus groups and interviews which were followed by a larger sample survey

17 administered both online and in-person. The following sections present the results of the focus

18 groups and then the larger sample survey. 
The primary goal of the focus groups was to better understand how individuals perceive the relative benefits and burdens of shared mobility within the local context of East Portland. Both focus groups were two-hour conversations administered in community spaces in East Portland during the summer of 2017. The first focus group engaged twelve members from Bus Riders Unite! (a bus riders' "union"). A second focus group was organized through the Latino Network community organization. Overall, the Latino Network group consisted of drivers, all middle-aged Hispanic females, who rarely use public transportation. The Bus Riders Unite! group was more diverse in terms of ethnicity and age, and had less access to private vehicles and used public transportation almost exclusively. Both groups were mostly lower to moderate income. The summaries which follow describe the major themes from the discussions.

Participants expressed a strong interest in opportunities for education and training on how to use smart mobility technology - especially smartphone applications (apps). These apps need to be available in users' native languages and should be translated to reflect the diversity of languages spoken by residents in East Portland. To maximize effective use of the apps, participants indicated that they would be interested in attending in-person trainings at trusted neighborhood institutions such as neighborhood schools, libraries, and nonprofit organizations or at TriMet stations. The need for cheaper, or free, access to data through public Wi-Fi type services was also highlighted.

Participants discussed multiple barriers to utilizing app-based technology. While most participants had some form of access to the internet either through a computer or via their smartphone, many raised concerns about security of mobility related apps. Some expressed concerns related to privacy of personal mobility (ability of data to be used to track movement). Participants also expressed major apprehensions about linking their bank accounts or credit cards to a smartphone apps citing concerns around security of their financial information (if phones were lost, stolen or hacked) and/or 'glitches' in the system that would delete their balances, credits or tickets. Roughly a third of participants did not have a checking or savings account, or even if they did, were afraid to connect them to their phone apps. One participant commented: "I have had my identity stolen before so I'm weary of anything automated." and another said: "I do have a bank account, but am afraid TriMet will use it and share it." There was a noticeable generational divide however between those with these concerns and younger participants, who were more trusting of the devices.

\section{SURVEYS}

As mentioned above, the study focus is on East Portland communities and so the survey sampling strategy focused on those areas. The use of an online survey, however, meant that it was harder to control exactly where survey participants lived. In the end, the sample included participants from all over Portland and Gresham, though still more concentrated in East Portland as was desired. Figure 1 shows the numbers of survey respondents from different areas of the region (mapped by zip code). The survey was implemented both online and in person using identical instruments and responses were merged. The study team visited groups and events led by people of color, and conducted intercept surveys on-board transit vehicles and at transit hubs in East Portland. The online survey was hosted on the OPAL website (OPAL 2017) and was 
open for responses during August and September of 2017. The link was shared through social media and emails from OPAL. A total of 308 surveys were received, 155 online and 153 inperson.

Even though a significant number of survey participants were from outside of the desired study area, the demographic profiles of the desired East Portland study area and the survey sample are fairly similar. A greater number of black or African-American respondents appear in the survey compared to their proportion of the study area, while Asians and Hispanics are underrepresented. Overall, the proportion of respondents of color in the survey (41\%) is similar to their proportion in the study area (47\%) (American Community Survey 2013-2017). The survey sample is overrepresentative of those under 54 years old, likely due to the internet-based distribution of the survey and the particular events in which the survey was administered in person (American Community Survey 2013-2017). The survey sample had lower annual incomes (a median of $\$ 35,000)$ than the study area population $(\$ 43,700)$ (American Community Survey 2013-2017).

\section{Equity Analysis Methodology}

The equity analysis is built only on the survey responses, and we compare results with focus group responses where applicable. This analysis looks at both the overall survey responses and also makes comparisons between subgroups to better understand the magnitude and significance of disparities in access to elements of the smart mobility ecosystem. To design our subgroups for comparison, this project reviewed key demographic indicators included in equity frameworks or analyses used in the Portland Metropolitan area (Metro 2018, TriMet 2017). To be consistent with those approaches, this analysis breaks the survey sample along the following three demographic dimensions: race/ethnicity, household income, and age. All of results in the tables presented in this paper are broken down into these groups. The responses were split fairly evenly between respondents of color $(\mathrm{N}=142)$ (herein POC) and white $(\mathrm{N}=158)$ (herein Non-Hispanic White (NHW)) respondents, while there were more low income (incomes less than 50,000 dollars per year) respondents $(\mathrm{N}=170)$ than high income $(\mathrm{N}=120)$. Looking at the survey responses broken down by age, Millennials (under 34 years old) represented half of the responses $(\mathrm{N}=155)$, with the remainder split between Baby Boomer (over 55 years old, herein called "Boomers") $(\mathrm{N}=40)$ and Generation X (35 to 54 years old, herein called "Gen-X") $(\mathrm{N}=$ 97). Grouping survey response data into these sub-groups allows the use of Chi-Square statistical tests to test whether the differences between groups are statistically significant. Where possible, we will also compare our results from national studies from the FDIC (2018 and 2018B) and 34 Pew Research Center (2015).

The survey contains nearly 40 questions and this paper presents a subset of the results and analyses from them. In the sections which follow, general results are presented followed by differences between our demographic groups. Sometimes tables are used to present the results, where overall results are shown alongside comparative analyses by the aforementioned demographic dimensions (age, income and race/ethnicity).

\section{$41 \quad$ Basic transportation access}

42 This initial section addresses access to vehicles, licensing and transportation benefits at school 43 and work (Table 2) to establish some baseline equity issues in transportation access. Overall, 
1 about $70 \%$ of respondents had access to a vehicle and $80 \%$ had a driver's license. Average

2 access to vehicles was quite low, however, with 1.13 vehicles per household. This is much lower

3 than the average for the City of Portland (1.49) (Governing.com 2017) and the country as a

4 whole (1.88) (McGuckin and Fucci 2018, p. 10). This area of East Portland in many ways

5 exemplifies the struggle among lower-income households for mobility, where automobiles offer

6 the best service though at high costs. While public transit service are fairly good in the region,

7 many residents in these more exurban areas, especially those wholly dependent on public transit,

8 end up trapped into smaller geographies of opportunity because of lower levels of mobility (see

9 Lubitow et al. (2016) for further exploration of these issues in this region).

11 Fewer, however received transportation benefits at work or school. Transit passes, free parking

12 and bicycle parking were the most common benefits with around a quarter receiving each while

13 very few people received the other benefits (company cars, electric vehicle charging and bike

14 sharing subscriptions). Almost $10 \%$ of the respondents experienced some mobility challenges.

16 Driver's licensing rates varied significantly by race and income, with higher income and NHW

17 respondents having higher rates of licensing. This finding is not surprising considering the State

18 of Oregon requires proof of legal residence to secure a driver's license. Among the other

19 dimensions, higher income respondents generally had better access to vehicles and transportation

20 benefits at the work or school location. For some benefits, younger respondents had better access

21 than older respondents (or perhaps were more aware of these benefits). Older respondents

22 reported significantly higher rates of mobility related disabilities. 
1 TABLE 2. Basic transportation access (part 1) ("Generation, Income and Race/ethnicity" 2 columns present data for each subgroup; NHW = Non-Hispanic White, $\mathrm{POC}$ = people of color; 3 Bolded numbers are differences which are statistically significant at $\mathrm{p} \geq 0.1$ ).

\begin{tabular}{|c|c|c|c|c|c|c|c|c|}
\hline & \multirow[t]{2}{*}{ Overall } & \multicolumn{3}{|c|}{ Generation } & \multicolumn{2}{|c|}{ Income } & \multicolumn{2}{|c|}{$\begin{array}{c}\text { Race/ } \\
\text { Ethnicity }\end{array}$} \\
\hline & & $\begin{array}{c}\text { Boomer } \\
\mathrm{N}=40\end{array}$ & $\begin{array}{l}\text { GenX } \\
\mathrm{N}=97\end{array}$ & $\begin{array}{c}\text { Mill. } \\
\mathrm{N}=155\end{array}$ & $\begin{array}{c}\text { High } \\
\mathrm{N}=120\end{array}$ & $\begin{array}{c}\text { Low } \\
\mathrm{N}=170\end{array}$ & $\begin{array}{c}\text { NHW } \\
\mathrm{N}=158\end{array}$ & $\begin{array}{c}\text { POC } \\
\mathrm{N}=142 \\
\end{array}$ \\
\hline $\begin{array}{l}\text { How many cars, trucks, vans, } \\
\text { or motorcycles are available in } \\
\text { your household for you to use? }\end{array}$ & 1.14 & 1.20 & 1.27 & 1.08 & 1.42 & 0.92 & 1.18 & 1.09 \\
\hline $\begin{array}{l}\text { Of the cars available to you, do } \\
\text { you lease, make payments, or } \\
\text { own them? [Multiple choice] } \\
(\%)\end{array}$ & 53 & 63 & 55 & 47 & 67 & 41 & 57 & 45 \\
\hline $\begin{array}{l}\text { Do you have a driver's license? } \\
{[\mathrm{Y} / \mathrm{N}](\%)}\end{array}$ & 79 & 80 & 79 & 80 & 95 & 70 & 89 & 67 \\
\hline $\begin{array}{l}\text { Do you experience some kind } \\
\text { of mobility related impairment } \\
\text { or disability? [Y/N] }(\%)\end{array}$ & 9.3 & 18 & 9.6 & 4.6 & 7.6 & 9.8 & 8.9 & 8.8 \\
\hline $\begin{array}{l}\text { Does your employer / school } \\
\text { provide you: } \\
\text { Transit pass? [Y/N] (\%) }\end{array}$ & 29 & 20 & 25 & 35 & 35 & 24 & 27 & 31 \\
\hline Free parking? $[\mathrm{Y} / \mathrm{N}](\%)$ & 23 & 28 & 25 & 23 & 28 & 19 & 26 & 21 \\
\hline $\begin{array}{l}\text { Secure bicycle parking? } \\
{[\mathrm{Y} / \mathrm{N}](\%)}\end{array}$ & 26 & 13 & 23 & 32 & 35 & 20 & 28 & 23 \\
\hline$(\%)$ Company vehicle? [Y/N] & 2.6 & 2.5 & 2.1 & 3.2 & 3.3 & 2.4 & 1.9 & 3.5 \\
\hline $\begin{array}{l}\text { Onsite electric vehicle } \\
\text { charger? [Y/N] }(\%)\end{array}$ & 5.2 & 5.0 & 5.2 & 5.8 & 10 & 1.8 & 7.6 & 2.8 \\
\hline $\begin{array}{l}\text { Biketown subscription? } \\
{[\mathrm{Y} / \mathrm{N}](\%)}\end{array}$ & 4.2 & 0.0 & 1.0 & 7.7 & 3.3 & 5.3 & 3.8 & 4.9 \\
\hline
\end{tabular}

The second set of questions concerned modes of travel to work and methods of payment for TriMet tickets (Table 3). Overall, the survey respondents were extremely diverse in their travel mode choices, with only $27.5 \%$ driving alone to work, much lower than the metro area's $70 \%$

8 (Metro 2018B) and nation's 76\% (McGuckin and Fucci 2018, p. 78). Consequently, rates of

9 bicycling, public transportation and walking are considerably higher than the metro area's (cycling, $\sim 2.5 \%$, public transit, $\sim 7 \%$, and walking, $\sim 3.5 \%$ ) and nation's (cycling, $\sim 1.1 \%$, public transit, $\sim 6.9 \%$, and walking, $\sim 2.9 \%$ ) (McGuckin and Fucci 2018, p. 78). This diversity of travel modes used reflects the general lack of private vehicle ownership and lower incomes. While this diversity is often the goals of implementing "smart mobility" policies and investments, many in this group are captive to non-private vehicle modes out of necessity, facing longer travel times and distances without the safer cycling, walking and transit infrastructure enjoyed by residents closer to the core of Portland.

It is well known that for car-less households, car use is facilitated through taxis, informally borrowed cars, carsharing or TNCs; the use of these modes by car-less households is disproportional to their share of the population (Brown 2019). While Rayle et al. (2015) showed that in San Francisco TNC users had higher incomes than the city residents overall, that doesn't necessarily contradict this study which focused only on the travel of relatively suburban low- 
me travelers with low car access. Brown's work indeed showed that low-income users of

2 TNCs made more trips per user than higher income users, corroborating our finding of higher

3 TNC use for work trips. Results by age group here corroborate disparities found in San Francisco

4 by Rayle et al (2015) and nationally (Schaller 2016) while the higher use by respondents of color

5 here is similar to the national finding (Schaller 2016)

There are important issues in how transit fare is paid for, with a significant number, around $40 \%$,

8 still relying on paying fares on board with cash. This poses a significant challenge to moving towards cashless mobility systems integrating with bank accounts and credit cards. This was a common theme brought up in the focus groups presented earlier, and is similarly born out in these quantitative survey results. Significantly, however, more than one third of respondents have moved to using online or phone applications to purchase fares. This is a positive development for the transition to smart mobility technologies. Cash payment showed significant differences along the dimensions of race/ethnicity and class, with lower income and respondents of color indicating a higher reliance on cash payment on board. On the contrary, higher income and NHW respondents showed more reliance on online and smart phone payments for fares.

TABLE 3. Basic transportation access (continued) ("Generation, Income and Race/ethnicity" columns present data for each subgroup; NHW = Non-Hispanic White, $\mathrm{POC}=$ people of color; Bolded numbers are differences which are statistically significant at $\mathrm{p} \geq 0.1$ ).

\begin{tabular}{|c|c|c|c|c|c|c|c|c|}
\hline & \multirow[t]{2}{*}{ Overall } & \multicolumn{3}{|c|}{ Generation } & \multicolumn{2}{|c|}{ Income } & \multicolumn{2}{|c|}{$\begin{array}{c}\text { Race/ } \\
\text { Ethnicity }\end{array}$} \\
\hline & & $\begin{array}{l}\text { Boomer } \\
\mathrm{N}=40\end{array}$ & $\begin{array}{l}\text { GenX } \\
N=97\end{array}$ & $\begin{array}{c}\text { Mill. } \\
\mathrm{N}=155\end{array}$ & $\begin{array}{c}\text { High } \\
\mathrm{N}=120\end{array}$ & $\begin{array}{c}\text { Low } \\
\mathrm{N}=170\end{array}$ & $\begin{array}{c}\text { NHW } \\
\mathrm{N}=158\end{array}$ & $\begin{array}{c}\text { POC } \\
\mathrm{N}=142\end{array}$ \\
\hline $\begin{array}{l}\text { The most common mode of } \\
\text { travel to work: } \\
\text { Drive alone [Y/N] (\%) }\end{array}$ & 28 & 25 & 31 & 26 & 34 & 22 & 27 & 29 \\
\hline Carpool [Y/N] (\%) & 5.2 & 2.5 & 3.1 & 7.7 & 2.5 & 7.6 & 3.8 & 7.0 \\
\hline $\begin{array}{l}\text { Public transportation [Y/N] } \\
(\%)\end{array}$ & 36 & 23 & 32 & 43 & 31 & 41 & 28 & 46 \\
\hline Walked [Y/N] (\%) & 12 & 5.0 & 11 & 14 & 7.5 & 15 & 9.5 & 15 \\
\hline Bicycle [Y/N] (\%) & 23 & 5.0 & 19 & 31 & 24 & 23 & 23 & 23 \\
\hline $\begin{array}{c}\text { Transportation Network } \\
\text { Companies (TNCs) [Y/N] }(\%)\end{array}$ & 2.3 & 0.0 & 3.1 & 2.6 & 0.0 & 4.1 & 1.3 & 3.5 \\
\hline Work at home $[\mathrm{Y} / \mathrm{N}](\%)$ & 5.5 & 12.5 & 8.2 & 2.6 & $\mathbf{1 0 . 0}$ & 2.9 & 8.9 & 2.1 \\
\hline $\begin{array}{l}\text { How do you typically pay for the } \\
\text { TriMet fare: } \\
\text { On board [Y/N] (\%) }\end{array}$ & 42 & 35 & 47 & 42 & 33 & 51 & 37 & 49 \\
\hline$(\%)$ TriMet or retail store $[\mathrm{Y} / \mathrm{N}]$ & 10 & 20 & 10 & 6.5 & 9.2 & 11 & 11 & 7.0 \\
\hline School or Work [Y/N] (\%) & 15 & 7.5 & 13 & 17 & 19 & 11 & 15 & 14 \\
\hline $\begin{array}{l}\text { Online or Phone App [Y/N] } \\
\%)\end{array}$ & 35 & 35 & 33 & 39 & 42 & 32 & 41 & 31 \\
\hline $\begin{array}{l}\text { Social service agency } \\
{[\mathrm{Y} / \mathrm{N}](\%)}\end{array}$ & 2.9 & 2.5 & 3.1 & 3.2 & 0.0 & 4.7 & 2.5 & 3.5 \\
\hline
\end{tabular}




\section{Access to data and internet}

2 The questions in this section address the issue of access to data, internet and smartphones (Table

3 4). Overall, access to internet was very high, with a small share, around $10 \%$, having no access to

4 the internet at home or work. This is significantly higher than national rates of access at home of

5 around 73\% (FDIC 2018, p.28). Similarly, smartphone use was very high at 89\%, again much

6 higher than national rates of around 73\% (FDIC 2018, p.28). In contrast to the high rates of

7 access to smartphones is the significant number $(25 \%)$ of respondents who had to cancel cell

8 phone service because of cost, similar to the $23 \%$ nationally who had to cut back on phone data

9 use due to data limitations (Pew 2015, p. 14).

Although statistical analyses showed there are significant disparities among the income and racial/ethnic groups, data and internet access across all groups was still quite high. For example, although nearly $100 \%$ of the NHW and higher income respondents had access to the internet at home and work, and more than $87 \%$ of respondents of color and low-income respondents had access. While there were disparities in smartphone use, they were because lower income and respondents of color had greater access than their counterparts, corroborating research from Pew (2015) but opposing results from FDIC (2018B). Boomers had markedly lower access to smartphones, at only $73 \%$.but this rate is higher than national rates

A significant and troubling disparity was in the area of cell data access. Lower income and respondents of color were about 10 percentage points more likely than average to have canceled cell service because of data plan limits and costs. And lower income and younger respondents were more likely to need to connect to Wi-Fi to reduce data use. This corresponds well with the previous research on this issue, as well as feedback from our focus group discussions where access to public Wi-Fi was seen as an important solution to improving the transition to smart mobility tools.

TABLE 4. Access to data and internet ("Generation, Income and Race/ethnicity" columns present data for each subgroup; NHW = Non-Hispanic White, $\mathrm{POC}=$ people of color; Bolded numbers are differences which are statistically significant at $p \geq 0.1$ ).

\begin{tabular}{|l|c|c|c|c|c|c|c|c|}
\hline \multirow{2}{*}{} & Overall & \multicolumn{3}{|c|}{ Generation } & \multicolumn{2}{c|}{ Income } & \multicolumn{2}{c|}{$\begin{array}{c}\text { Race/ } \\
\text { Ethnicity }\end{array}$} \\
\cline { 2 - 8 } & & $\begin{array}{c}\text { Boomer } \\
\mathrm{N}=40\end{array}$ & $\begin{array}{c}\text { GenX } \\
\mathrm{N}=97\end{array}$ & $\begin{array}{c}\text { Mill. } \\
\mathrm{N}=155\end{array}$ & $\begin{array}{c}\text { High } \\
\mathrm{N}=120\end{array}$ & $\begin{array}{c}\text { Low } \\
\mathrm{N}=170\end{array}$ & $\begin{array}{c}\text { NHW } \\
\mathrm{N}=158\end{array}$ & $\begin{array}{c}\text { POC } \\
\mathrm{N}=142\end{array}$ \\
\hline $\begin{array}{l}\text { How frequently do you use email } \\
\text { and/or the internet? [Frequency, } \\
\text { times per month - translated from } \\
\text { the different frequency options } \\
\text { (daily, weekly, etc.) in the survey] }\end{array}$ & 89 & $\mathbf{7 3}$ & $\mathbf{9 0}$ & $\mathbf{9 4}$ & $\mathbf{9 6}$ & $\mathbf{8 4}$ & $\mathbf{9 3}$ & $\mathbf{8 5}$ \\
\hline $\begin{array}{l}\text { At your home, do you have access } \\
\text { to the internet? [Y/N] (\%) }\end{array}$ & 92 & 88 & 94 & 94 & $\mathbf{9 8}$ & $\mathbf{8 8}$ & $\mathbf{9 7}$ & $\mathbf{8 7}$ \\
\hline $\begin{array}{l}\text { If you work, at your workplace, } \\
\text { do you have access to the } \\
\text { internet? [Y/N] (\%) }\end{array}$ & 93 & 91 & 94 & 93 & $\mathbf{9 9}$ & $\mathbf{8 7}$ & $\mathbf{9 7}$ & $\mathbf{8 9}$ \\
\hline $\begin{array}{l}\text { Is your cell phone a smartphone? } \\
\text { [Y/N] (\%) }\end{array}$ & 89 & $\mathbf{7 3}$ & $\mathbf{8 9}$ & $\mathbf{9 4}$ & 89 & 89 & $\mathbf{8 9}$ & $\mathbf{9 1}$ \\
\hline $\begin{array}{l}\text { If you have a cell phone, how } \\
\text { frequently do you use public Wi- } \\
\text { Fi in order to reduce your data }\end{array}$ & 68 & $\mathbf{4 3}$ & $\mathbf{6 7}$ & $\mathbf{7 4}$ & $\mathbf{6 3}$ & $\mathbf{7 2}$ & 68 & 68 \\
\hline
\end{tabular}




\begin{tabular}{|l|l|l|l|l|l|l|l|l|}
\hline $\begin{array}{l}\text { use? [Multiple Choice] (\% } \\
\text { choosing "whenever possible" or } \\
\text { "occasionally") }\end{array}$ & & & & & & & \\
\hline $\begin{array}{l}\text { Have you ever had to cancel your } \\
\text { cell phone service for a period of } \\
\text { time because of cost? [Y/N] (\%) }\end{array}$ & 25 & 16 & 25 & 26 & $\mathbf{1 3}$ & $\mathbf{3 5}$ & $\mathbf{1 8}$ & $\mathbf{3 3}$ \\
\hline
\end{tabular}

\section{Access to banking and credit}

3 Overall, access to banking and credit is high with $72 \%$ having access to credit and $90 \%$ having 4 access to banking services (Table 5). These results are similar to those found by the FDIC (2018)

5 showing that $6.5 \%$ of the overall population was completely unconnected to the mainstream

6 banking system (p. 1) and 31\% lacked access to credit (p. 48), with higher rates of exclusion for

7 low-income and minority households. Rates found here for low-income respondents and

8 respondents of color are similar to the findings from New York (King and Saldarriaga 2017).

9 Notably, comfort with linking personal financial information to phone applications was

10 significantly higher for younger, NHW and higher income respondents, even though younger

11 respondents had less access to banking and credit compared to older respondents. Older

12 residents, who showed the least comfort of any group, may need additional training for them to

13 become comfortable trusting these applications (corroborating Shirgaokar (2018)).

TABLE 5. Access to banking and credit ("Generation, Income and Race/ethnicity" columns present data for each subgroup; NHW = Non-Hispanic White, $\mathrm{POC}=$ people of color; Bolded numbers are differences which are statistically significant at $p \geq 0.1$ ).

\begin{tabular}{|l|c|c|c|c|c|c|c|c|}
\hline & Overall & \multicolumn{3}{|c|}{ Generation } & \multicolumn{2}{c|}{ Income } & \multicolumn{2}{c|}{$\begin{array}{c}\text { Race/ } \\
\text { Ethnicity }\end{array}$} \\
\cline { 2 - 8 } & & $\begin{array}{c}\text { Boomer } \\
\mathrm{N}=40\end{array}$ & $\begin{array}{c}\text { GenX } \\
\mathrm{N}=97\end{array}$ & $\begin{array}{c}\text { Mill. } \\
\mathrm{N}=155\end{array}$ & $\begin{array}{c}\text { High } \\
\mathrm{N}=120\end{array}$ & $\begin{array}{c}\text { Low } \\
\mathrm{N}=170\end{array}$ & $\begin{array}{c}\text { NHW } \\
\mathrm{N}=158\end{array}$ & $\begin{array}{c}\text { POC } \\
\mathrm{N}=142\end{array}$ \\
\hline $\begin{array}{l}\text { Do you have a credit card or } \\
\text { prepaid card account? [Y/N] (\%) }\end{array}$ & 72 & $\mathbf{8 5}$ & $\mathbf{7 8}$ & $\mathbf{6 6}$ & $\mathbf{9 0}$ & $\mathbf{6 0}$ & $\mathbf{7 9}$ & $\mathbf{6 4}$ \\
\hline $\begin{array}{l}\text { Do you have a checking or } \\
\text { savings account? [Y/N] (\%) }\end{array}$ & 90 & 95 & 93 & 86 & $\mathbf{9 8}$ & $\mathbf{8 5}$ & $\mathbf{9 5}$ & $\mathbf{8 4}$ \\
\hline $\begin{array}{l}\text { How comfortable are you in } \\
\text { linking your bank account or } \\
\text { credit card to transportation apps } \\
\text { on your phone? [Likert scale - } \\
\text { range 1 to 5] (Average score) }\end{array}$ & 3.3 & $\mathbf{2 . 7}$ & $\mathbf{3 . 2}$ & $\mathbf{3 . 6}$ & $\mathbf{3 . 7}$ & $\mathbf{3 . 1}$ & $\mathbf{3 . 6}$ & $\mathbf{3 . 0}$ \\
\hline
\end{tabular}

\section{Smart mobility applications}

This section of questions focused on the use of currently existing smart mobility applications, including public transportation information, navigation, ridesourcing and bike sharing (Table 6).

22 The use of smart phone applications for public transit and navigation was quite high, with overall

23 usage averaging around four times per week. The use of smart phone applications for TNCs and

24 bike sharing were much lower at only a day or two per month. Interestingly, there were fewer

25 equity concerns as lower income respondents and respondents of color used these applications

26 similarly, and sometimes more than their counterparts. The one significant disparity in these 
results is that younger respondents use these applications more frequently by a significant margin (more than twice as much). This may be due to the higher access and use of private vehicles by

3 respondents in the Boomer generation compared to Millennials; there is simply less need for

4 these tools for the Boomer respondents. These results corroborate those found in the Los Angeles case (Brown 2019) but differ from the national study by Feigon and Murphy (2018) which showed higher use in whiter neighborhoods (other than Seattle).

TABLE 6. Use of smart mobility applications ("Generation, Income and Race/ethnicity" columns present data for each subgroup; NHW = Non-Hispanic White, $\mathrm{POC}=$ people of color; Bolded numbers are differences which are statistically significant at $p \geq 0.1$ ).

\begin{tabular}{|l|c|c|c|c|c|c|c|c|}
\hline & Overall & \multicolumn{3}{|c|}{ Generation } & \multicolumn{2}{c|}{ Income } & \multicolumn{2}{c|}{$\begin{array}{c}\text { Race/ } \\
\text { Ethnicity }\end{array}$} \\
\cline { 2 - 8 } & & $\begin{array}{c}\text { Boomer } \\
\text { N=40 }\end{array}$ & $\begin{array}{c}\text { GenX } \\
\text { N=97 }\end{array}$ & $\begin{array}{c}\text { Mill. } \\
\text { N=155 }\end{array}$ & $\begin{array}{c}\text { High } \\
\text { N=120 }\end{array}$ & $\begin{array}{c}\text { Low } \\
\text { N=170 }\end{array}$ & $\begin{array}{c}\text { NHW }=158 \\
\text { N= }\end{array}$ & $\begin{array}{c}\text { POC } \\
\text { N }\end{array} 142$ \\
\hline $\begin{array}{l}\text { If you have a smartphone, how } \\
\text { often do you use your phone to } \\
\text { get public transportation } \\
\text { information? [Days per Month] }\end{array}$ & 13.4 & $\mathbf{6 . 7}$ & $\mathbf{1 1 . 8}$ & $\mathbf{1 5 . 6}$ & $\mathbf{9 . 0}$ & $\mathbf{1 6 . 3}$ & $\mathbf{1 1 . 5}$ & $\mathbf{1 5 . 1}$ \\
\hline $\begin{array}{l}\text { If you have a smartphone, how } \\
\text { often do you use your phone for } \\
\text { navigation? [Days per Month] }\end{array}$ & 15.8 & $\mathbf{7 . 6}$ & $\mathbf{1 4 . 8}$ & $\mathbf{1 8 . 1}$ & 14.8 & 17.1 & 14.8 & 16.7 \\
\hline $\begin{array}{l}\text { If you have a smartphone, how } \\
\text { often do you use your phone to } \\
\text { reserve a ridesourcing or } \\
\text { carsharing service? [Days per } \\
\text { Month] }\end{array}$ & 2.2 & $\mathbf{1 . 4}$ & $\mathbf{2 . 0}$ & $\mathbf{2 . 4}$ & $\mathbf{1 . 8}$ & $\mathbf{2 . 7}$ & 1.5 & 2.9 \\
\hline $\begin{array}{l}\text { If you have a smartphone, how } \\
\text { often do you use your phone to } \\
\text { use bikesharing? [Days per } \\
\text { Month] }\end{array}$ & 1.2 & $\mathbf{1 . 3}$ & $\mathbf{0 . 6}$ & $\mathbf{1 . 2}$ & $\mathbf{1 . 0}$ & $\mathbf{1 . 3}$ & $\mathbf{1 . 0}$ & $\mathbf{1 . 5}$ \\
\hline
\end{tabular}

\section{Policy recommendations}

13 Survey respondents were given a list of 10 policies from which they could vote for their favorite three to address barriers to using smart mobility systems (Table 7). Improved real-time transportation information for public transit users and public Wi-Fi and charging stations were closely matched as the two most preferred overall. Interestingly, low income, Millennials, and respondents of color preferred the public Wi-Fi as their top choice while Boomers, Gen-X, wealthier and NHW respondents preferred the real-time communication as their top choice. Third and fourth choices included addressing language issues in smart phone applications and providing financial assistance for the purchase of electric vehicles. Coming in fifth was interest in autonomous neighborhood shuttles to access transit stations. Boomers were especially interested in expansion of Bikeshare availability and more electric vehicle charging stations, things the other groups ranked much lower. Interestingly, Boomers were not any more interested in outreach and education than other groups. 
TABLE 7. Ranking of policy preferences (share (\%) of votes cast) (Each survey respondent

2 could vote for three options. The top four scores, sometimes including ties, are bolded, the top

3 two are underlined, for each group.)

\begin{tabular}{|c|c|c|c|c|c|c|c|c|}
\hline Policies & Overall & $\begin{array}{l}\text { Boomer } \\
\mathrm{N}=40\end{array}$ & $\begin{array}{l}\text { GenX } \\
\mathrm{N}= \\
97\end{array}$ & $\begin{array}{r}\text { Mill. } \\
\mathrm{N}=155\end{array}$ & $\begin{array}{l}\text { High } \\
\mathrm{N}= \\
120\end{array}$ & $\begin{array}{l}\text { Low } \\
\mathrm{N}= \\
170\end{array}$ & $\begin{array}{l}\text { NHW } \\
\mathrm{N}= \\
158\end{array}$ & $\begin{array}{l}\text { POC } \\
\mathrm{N}= \\
142\end{array}$ \\
\hline $\begin{array}{l}\text { Real time communication between } \\
\text { buses and riders about crowding, } \\
\text { arrival time, etc. }\end{array}$ & $\underline{16.3}$ & 17.4 & $\underline{18.5}$ & $\underline{15.2}$ & $\underline{15.2}$ & $\underline{16.0}$ & 16.4 & 16.5 \\
\hline $\begin{array}{l}\text { Public Wi-Fi and charging stations for } \\
\text { smartphone/mobile technology }\end{array}$ & $\underline{15.7}$ & $\underline{12.4}$ & $\underline{14.4}$ & $\underline{17.5}$ & 11.7 & $\underline{18.9}$ & $\underline{15.1}$ & $\underline{16.8}$ \\
\hline $\begin{array}{l}\text { Rebates or financing to help buy clean } \\
\text { electric vehicles }\end{array}$ & 12.3 & 10.7 & 14.4 & 12.2 & $\underline{15.0}$ & 10.8 & 13.8 & 10.4 \\
\hline $\begin{array}{l}\text { Smartphone applications for } \\
\text { transportation services translated to } \\
\text { languages other than English }\end{array}$ & 10.9 & 7.4 & 9.5 & 12.0 & 9.1 & 12.4 & 10.2 & 11.4 \\
\hline $\begin{array}{l}\text { Self-driving neighborhood shuttles to } \\
\text { bring people to transit stops }\end{array}$ & 9.9 & 9.9 & 11.1 & 9.4 & 12.0 & 8.5 & 9.6 & 10.4 \\
\hline $\begin{array}{l}\text { Expansion of the Biketown bike-share } \\
\text { program outside of central } \\
\text { neighborhoods }\end{array}$ & 8.6 & 11.6 & 6.6 & 8.8 & 10.3 & 7.5 & 9.8 & 6.6 \\
\hline $\begin{array}{l}\text { Expansion of carsharing services that } \\
\text { allow short-term vehicle rentals to } \\
\text { more neighborhoods }\end{array}$ & 8.0 & 8.3 & 7.4 & 7.9 & 9.1 & 7.5 & 9.4 & 6.1 \\
\hline $\begin{array}{l}\text { More public outreach and education } \\
\text { about different mobility options like } \\
\text { carsharing, Biketown, etc. }\end{array}$ & 7.4 & 5.8 & 6.2 & 7.9 & 7.6 & 7.3 & 6.2 & 8.8 \\
\hline More electric vehicle charging stations & 6.6 & $\underline{12.4}$ & 7.4 & 4.9 & 8.2 & 5.4 & 7.7 & 5.6 \\
\hline $\begin{array}{l}\text { More public outreach and education } \\
\text { around smartphone applications for } \\
\text { transportation services }\end{array}$ & 4.3 & $\overline{4.1}$ & 4.5 & 4.3 & 1.8 & 5.8 & 1.9 & 7.4 \\
\hline
\end{tabular}

These preferences mirror qualitative responses collected in open ended survey responses and comments made by focus group participants. Specifically, three of the five most popular policies expand the capacity of residents to use their smartphones as tools to access mobility services.

8 The policies of expanding real-time communication between transit vehicles, investing in public

9 Wi-Fi and charging stations for smartphones, and ensuring translation of mobility apps to

10 multiple languages were named as specific barriers by focus group participants.

Respondents were also asked about how they would want to receive such trainings and the clear preference was for online materials. This result may be related to the fact that half of surveys were carried out online, but the high rate of access to internet and smart phones indicated this may be a best option nonetheless. Considering the cost and logistical challenge of in-person trainings, those could be carried out in a more limited fashion, perhaps focusing on older residents who did respond that they preferred printed materials.

19 If in-person training were required, respondents were asked to give their preferences about how

20 they would want to receive that information. Those rankings highlighted public libraries, TriMet

21 facilities and in third place, community centers as the preferred locations and institutions to

22 convene such activities. It would be quite easy for the City of Portland to collaborate with 
regional service providers such as TriMet or the Multnomah County Library to develop outreach and educational programs about smart mobility options.

CONCLUSIONS

We organize the key overall conclusions from these results by the original research questions guiding this study. The first question was: "How can smart mobility technologies address the current and future needs of transportation disadvantaged communities?"

Various results from this study address this question. One of the most interesting takeaways was how the low income and respondents of color (and others, though to a lesser extent) in East Portland are highly diverse in their mode choices compared to their regional and national counterparts. Lower vehicle ownership, lower incomes, and lower licensure rates mean that the transportation disadvantaged communities in East Portland rely heavily on modes other than the private automobile. Unfortunately, this also means they are able to reach fewer of the region's opportunities, as transit service is less dense outside of the regional core. As far as smart mobility technologies can facilitate, and make cheaper and more convenient, alternatives to private automobile ownership it is clear that smart mobility technologies have the potential to address many of the current and future transportation needs of transportation disadvantaged communities. Indeed, low income respondents and respondents of color not only chose more diverse travel options, but they are more regular users of currently available mobility tools such as smartphone applications for accessing public transportation and ridesharing services such as Uber and Lyft. This pattern corroborates findings in the literature about the use of taxis and TNCs among low-income and car-less households, seeking improved (but costly) mobility from automobiles through these other means (e.g. Shaller 2016, Brown 2019, Dill et al. 2017). (The important social justice questions surrounding TNC driver rights, earnings, etc. should not be forgotten, though it is well outside of the scope of this discussion.) Considering the interest in improving real-time public transportation information and scheduling applications, it seems that smart mobility technologies are particularly poised to address those needs. Furthermore, low income respondents and respondents of color had similar access to smartphones compared to their counterparts (even though access to cell data may still be deficient).

The second research question guiding this work was the following: "What are the barriers to using smart mobility technologies experienced by different communities?" Several barriers were highlighted in this work, most of which corroborate results from the wider literature. One barrier is the lower access to drivers' licenses, bank accounts and credit cards among lower income respondents and respondents of color in East Portland. These disparities mirror national data on these issues, and is a concern noted in much of the existing literature. While licensing may be less relevant as new smart mobility services often replace individuals driving themselves, it is still important as the current offerings include various carsharing options (and in some places escooters). Since integrating convenient payment systems, like credit cards, into the transportation applications is a core feature of smart mobility systems, this disparity is a severe barrier to the equitable transition to smart mobility. This disparity is also evident in how low income respondents and respondents of color rely more heavily on paying cash on board for transit fares. While there are some ways to address this problem, they tend to be less than ideal; Some systems have begun to offer cash payment workarounds including making cash payments to drivers, offering debit card programs, using money orders or paying in cash at retail locations to load 
accounts using systems like "PayNearMe" (Shaller 2016). The case presented here further corroborates the evidence that digital and banking access remain a serious issue for many communities. Interestingly, this case differed from previous work

There is also the lower comfort in connecting financial information to applications and the lower ownership of smart phones among Baby-Boomer respondents, similar to results found in the Canadian study (Shirgaokar 2018). A transition to smart mobility, which may render traditional single occupant automobile travel more costly or difficult, will be more challenging for these Boomer respondents without an effort to train them. Shirgaokar (2018) also makes other recommendations to improve the user experience and trust and adapt new mobility technologies to the needs of older residents.

This discomfort with sharing personal financial information should not be underestimated by planners and city staff. As many low income and older community members are already in precarious financial situations, identity theft or losing funds from online or smart phone accounts could have devastating impacts. Older adults are under constant pressure from schemes to steal identity and financial information. Higher income households can often absorb these losses or use banks or credit card companies which forgive fraudulent activity when it happens against their accounts. These insurances are not shared by everyone, so the idea of information security should be taken quite seriously. This concern was expressed many times during the focus groups and in open-ended survey responses.

Another barrier is the access to data and internet, an issue noted throughout the existing literature. Higher income and NHW respondents had greater access to internet both at home and at work and were less likely to need to reduce data use or cancel cell plans because of cost or data restrictions. As the emerging smart mobility ecosystem will rely on smartphones and larger data transmissions, these issues are especially important. Indeed, public Wi-Fi was the highest ranked policy recommendation among the options offered for selection in the survey, and was mentioned numerous times during the focus groups.

The third research question guiding this project was: "What potential solutions show the most promise in overcoming these barriers?" The overall highest ranked recommendation from the surveys was to facilitate public transportation information, scheduling and route finding through improved real-time communication to users through smart applications and open data sharing through APIs (even for private sector services). How this improves on current tools available is an open question but for many public transit users facing crowding on certain routes or needing additional room for strollers, carts or wheelchairs, better information about in-vehicle conditions and crowding were common requests. It seems very much within the purview of smart mobility applications to provide these improved tools, though it will also be important for mobility companies and public transit operators to facilitate open data access and sharing through APIs something that is not currently available for TNCs and many other companies.

Based on the survey responses but also the extensive comments received through the focus groups and open-ended survey questions it was clear that more public support for data access (such as though public Wi-Fi or information kiosks) was also a top priority. Policies or investment to improve internet and data access could also be pinpointed to a small number of 
1 households to yield a large reduction in this disparity. Also high priorities were to lower barriers

2 to purchasing or using electric vehicles and expanding translation for important transportation

3 applications into languages other than English. The latter recommendation was very common in

4 the focus group discussions, and would integrate clearly with the public mission of a publicly

5 managed smart mobility platform with the goal of providing universal access and usability.

6 While respondents preferred to receive trainings using online methods, if trainings or outreach

7 were to occur they preferred public spaces such as community centers, TriMet facilities, or

8 public libraries (in contrast with individual organizations or churches).

10 Overall, this case study largely corroborates previous research on these issues and points to some

11 significant and positive contributions that smart mobility technologies could have to improve the

12 mobility of transportation disadvantaged communities in Portland. As smart mobility

13 technologies facilitate mobility without the private automobile, this can improve transportation

14 systems already used by the transportation disadvantaged by improving service or lowering

15 costs. Still, there are formidable barriers, especially in access to credit, banking, and affordable

16 cell and internet service, which could leave many people behind. Just as the freeway, the suburb

17 and the private automobile left many behind, while few planners at the time predicted any

18 negative impacts, we can do better. This research project is part of an effort of anticipatory

19 governance for the Portland region: Understanding barriers and posing questions as the

20 technologies are being developed, and not after. Hopefully this case study can be relevant to

21 similar processes of smart mobility deployment in other cities around the world. 


\section{ACKNOWLEDGEMENTS}

2 This project was funded by grants from Forth, the 11th Hour Project (of the Schmidt Family

3 Foundation), and the National Institute for Transportation and Communities (NITC) at Portland

4 State University (Project \#1163), a U.S. DOT University Transportation Center, with assistance

5 from the City of Portland. 


\section{REFERENCES}

Acheampong, R.A., Thomoupolos, N., Marten, K., Beyazit, E., Cugurullo, F., \& Dusparic, I. (2018). Literature Review on the Social Challenges of Autonomous Transport. Short Term Scientific Mission Report for COST Action CA16222 "Wider Impacts and Scenario Evaluation of Autonomous and Connected Transport (WISE-ACT).

Alessandrini, A., Campagna, A., Site, P. D., Filippi, F., \& Persia, L. (2015). Automated Vehicles and the Rethinking of Mobility and Cities. Transportation Research Procedia, 5, 145-160.

Brakewood, C. \& Kocur, G. (2013). Unbanked Transit Riders and Open Payment Fare Collection. Transportation Research Record, Volume 2351, pp. 133-141.

Brown, A. (2019) Redefining Car Access, Journal of the American Planning Association, 85:2, 83-95.

Brown, A. (2018) Ridehail Revolution: Ridehail Travel and Equity in Los Angeles. UCLA Doctoral Dissertation.

Coalition of Communities of Color, Ecotrust, Futurewise, \& 1000 Friends of Oregon (2017) Regional Equity Atlas. http://www.regionalequityatlas.org/home

Dill, J., McNeil, N. \& Howland, S. (2017) Peer-To-Peer Carsharing: Short-Term E $\square$ ects on Travel Behavior in Portland, OR. TREC-RR-1144. Portland, OR: Transportation Research and Education Center.

Dinning, M. \& Weisenberger, T. (2017). Multimodal Transportation Payments ConvergenceKey to Mobility. Disrupting Mobility, 121-133.

Feigon, S. \& Murphy, C. (2018) Broadening Understanding of the Interplay Among Public Transit, Shared Mobility, and Personal Automobiles. Washington, DC: The National Academies Press

Federal Deposit Insurance Corporation (FDIC) (2018). 2017 National Survey of Unbanked and Underbanked Households. https://www.fdic.gov/news/news/press/2018/pr18077.html

Federal Deposit Insurance Corporation (FDIC) (2018B). 2017 National Survey of Unbanked and Underbanked Households - Appendix Tables.

Gehrke, S., Felix, A., \& Reardon, T. (2018). Fare choices: A survey of ride-hailing passengers in metro Boston. Metropolitan Area Planning Council Research Brief.

Golub, A., M. Serritella, V. Satterfield \& J. Singh. (2018) Community-Based Assessment of Smart Transportation Needs in the City of Portland. NITC-RR1163. Portland, OR: Transportation Research and Education Center (TREC).

Governing.com. Vehicle Ownership in U.S. Cities Data and Map. https://www.governing.com/gov-data/car-ownership-numbers-of-vehicles-by-city-map.html

Gruel, W. \& Stanford, J. (2016). Assessing the Long-Term Effects of Autonomous Vehicles: A Speculative Approach. Transportation Research Procedia, 13, 18-29.

Grush, B. \& Niles, J. (2017). Transit Leap: A Deployment Path for Shared-Use Autonomous Vehicles that Supports Sustainability. Disrupting Mobility, 291-305.

Hörl, S., Ciari, F., \& Axhausen, K. (2016). Recent Perspectives on the Impact of Autonomous Vehicles. Institute for Transportation Planning and System, 1-37.

Howland, S., McNeil, N., Broach, J., Rankins, K., MacArthur, J., \& Dill, J. (2017). Current Efforts to Make Bikeshare More Equitable: Survey of System Owners and Operators. Transportation Research Record, 2662(1), 160-167. https://doi.org/10.3141/2662-18 
Iacobucci, J., Hovenkotter, K., \& Anbinder, J. (2017). Transit Systems and the Impact of Shared Mobility. Disrupting Mobility, 65-76.

King, D \& Saldarriaga, J. (2017). Access to Taxicabs for Unbanked Households: An Exploratory Analysis in New York City. Journal of Public Transportation, 20 (1): 1-19.

Kodransky, M., \& Lewenstein, G. (2014). Connecting Low-Income People to Opportunity with Shared Mobility. Institute for Transportation and Development Policy and Living Cities. https://www.itdp.org/wp-content/uploads/2014/10/Shared-Mobility Full-Report.pdf

Kramer, A. \& Goldstein, A. (2015). Meeting the Public's Need for Transit Options: Characteristics of Socially Equitable Transit Networks. Institute of Transportation Engineers Journal, 85:9, 23-30.

Litman, T. A. (2017). Autonomous Vehicle Implementation Predictions: Implications for Transport Planning. Victoria Transport Policy Institute, 1-23.

Lubitow, A., Mahmoudi, D., \& Lillard, L. (2016). Understanding Spatial Equity in Portland, Oregon. 1-27. Portland State University Working paper. https://www.pdx.edu/sociology/sites/www.pdx.edu.sociology/files/Spatial $\% 20$ Equity $\% 20 \mathrm{Re}$ port.pdf

Mattioli, G. \& Colleoni, M. (2016). Transportation Disadvantage, Car Dependence and Urban Form. Understanding Mobilities for Designing Contemporary Cities, 171-190.

McNeil, N., Dill, J., MacArther, J., Broach, J., \& Howland, S. (2017). Breaking Barriers to Bike Share: Insights on Equity. Transportation Research and Education Center (TREC). 1-20

OPAL. (2017) Transportation survey. http://www.opalpdx.org/2017/08/transportation-needsassessment/ Accessed July. 5, 2018.

McGuckin, N. \& Fucci, A. (2018) Summary of Travel Trends: 2017 National Household Travel Survey. Washington D.C.: Federal Highway Administration (Report FHWA-PL-18-019).

Metro (Portland, Oregon) (2018) 2018 Regional transportation plan - Public Review Draft, Appendix E - Transportation Equity Evaluation https://www.oregonmetro.gov/sites/default/files/2018/06/29/RTPAppendix_E_2018_RTP_Transportation_Equity_Evaluation_with_attachments.pdf Accessed July. 5, 2018.

Metro (Portland, Oregon) (2018B) Oregon Metro's Regional Snapshots https://www.oregonmetro.gov/regional-snapshots Accessed July 7, 2018.

Pew Research Center (Pew) (2015) The Smartphone Difference. Available at: http://www.pewinternet.org/2015/04/01/us-smartphone-use-in-2015/

Portland Bureau of Transportation (PBOT) (2018) Smart Cities Framework https://www.portlandoregon.gov/transportation/69999

Rayle, L., Dai, D., Chan, N., Cervero, R., \& Shaheen, S. (2016). Just a better taxi? A survey based comparison of taxis, transit, and ridesourcing services in San Francisco. Transport Policy 45, 168-178.

Rode, P., Floater, G., Thomopoulos, N., Docherty, J., Schwinger, P., Mahendra, A., \& Fang, W. (2017). Accessibility in Cities: Transport and Urban Form. Disrupting Mobility, 239-273.

Schaller, B. (2016). Between public and private mobility examining the rise of technologyenabled transportation services: Taxi, sedan, and limousine industries and regulations. TRB Special Report 319. Washington, DC: Transportation Research Board

Shaheen, S., Bell, C., Cohen, A., \& Yelchuru, B. (2017). Travel behavior: Shared mobility and transportation equity. Federal Highway Administration Report No. PL-18-007. 
1 Shirgaokar, M. (2018) Expanding Seniors' Mobility through Phone Apps: Potential Responses

2 from the Private and Public Sectors. Journal of Planning Education and Research, 1. 1.

3 TriMet (2017) Communities of concern, definitions.

$4 \quad$ https://www.arcgis.com/home/item.html?id=a411529283e34385a853f41dc8742e29

5 Accessed July. 5, 2018.

6 Velaga, N., Beecroft, M., Nelson, J., Corsar, D., \& Edwards, P. (2012). Transport poverty meets

7 the digital divide: accessibility and connectivity in rural communities. Journal of Transport

8 Geography, 21, 102-112. 